\title{
Degradation kinetics of metronidazole and its mutual prodrug with ciprofloxacin: a calorimetric analysis
}

\author{
Renu CHADHA ${ }^{1, *}$, Amit AGGARWAL ${ }^{1}$, D.V.S. JAIN ${ }^{2}$, V.K. KAPOOR ${ }^{1}$, Deepika \\ THAKUR $^{1}$ and Aarti SHARMA ${ }^{1}$ \\ ${ }^{1}$ University Institute of Pharmaceutical Sciences, Panjab University, Chandigarh, India. \\ 2 Department of Chemistry, Panjab University, Chandigarh, India. \\ *Corresponding author, Tel: 91-172-2534104, Email: renukchadha2004@yahoo.co.in
}

\begin{abstract}
Calorimetric technique has aroused considerable interest as a versatile tool in pharmaceutical industry and academia to provide useful information about thermodynamic and kinetic aspects of drug molecules. The present paper utilizes this technique to monitor the hydrolytic degradation of metronidazole and its prodrug with ciprofloxacin, i.e. 2-(2-methyl-5-nitroimidazol-1-yl)ethyl-1-cyclopropyl-6-fluoro-1,4-dihydro-4-oxo-7-(1piperazinyl)-quinoline-3-carboxylate. The synthesis of the present mutual prodrug was envisaged to combine the antiprotozoal and anaerobic antibacterial effects of metronidazole with antibacterial effects of ciprofloxacin. Heat flux microcalorimeter was used to determine the rate of heat evolved during the degradation of the drug and prodrug as a function of concentration, $\mathrm{pH}$ and temperature. In terms of enthalpy of hydrolysis the response is exothermic both for drug and prodrug. However, the absolute value of the enthalpy of reaction $\left(\Delta_{\mathrm{r}} \mathrm{H}^{0}\right)$ is low for the prodrug. The degradation followed pseudo first order kinetics, showed marked stability at $\mathrm{pH}$ 3-7 followed by accelerated hydrolysis at higher $\mathrm{pH}$, characteristic of general acid-base catalysis. The catalytic rate constant for hydrogen ion $\left(\mathrm{k}_{\mathrm{H}}\right)$ and hydroxyl ion $\left(\mathrm{k}_{\mathrm{OH}}\right)$ were found to be 0.413 and $526.1 \mathrm{M}^{-1} \mathrm{~h}^{-1}$, respectively, at $318.15 \mathrm{~K}$. The hydrolysis of the prodrug was found to be approximately 50-60 times faster than that of the drug. This may be attributed to the fact that hydrolysis of ester group in prodrug is assisted by keto group on the ciprofloxacin. However, there is no effect of protonation of nitrogen in piperazine ring in ciprofloxacin on the hydrolysis due to the distance from the ester moiety.
\end{abstract}

(C) 2007 International Formulae Group. All rights reserved.

Keywords: Calorimetry, stability studies, degradation kinetics, ciprofloxacin, metronidazole.

\section{INTRODUCTION}

Metronidazole is one of the rare examples of a drug developed against protozoa which has since gained broad use as an antibacterial agent (Freeman et al., 1997; Samuelson, 1999; O'Keefe et al., 1982). For some of the possible infections for which metronidazole might be used, there are very few alternatives. It is often prescribed along with other antibacterials which have the advantage of having broad spectrum of activity and are effective against both bacteria and protozoa (Werk et al., 1988; Shen et al., 2001; Prantera et al., 1996; Goldstein et al., 1991; Houben et al., 1999; Whiting et al., 1987; Ralph et al., 1980; Pavicić et al., 1992).
Ciprofloxacin is one of the most important members of the fluoroquinolone antibacterials having a wide range of antibacterial activity. It is advantageous to combine the antiprotozoal and anaerobic antibacterial action of metronidazole with antibacterial action of ciprofloxacin to form a broad spectrum chemotherapeutic agent (Werk et al., 1988; Mimura et al., 2002) by synthesizing a mutual prodrug. The alcoholic functional group in metronidazole is readily esterifiable and therefore, it appeared to be possible to obtain ester derivatives providing the desired improvement in water solubility (Vermeersch et al., 1990) and at the same time possessing a high susceptibility to undergo enzymatic 
hydrolysis in the body (Yang et al., 2001; Mahtouz et al.,1998; Johnansen et al., 1984; Johnansen et al., 1985).

We report here the synthesis of this prodrug and the kinetics of its hydrolysis using the technique of calorimetry. However, it is known in the literature that metronidazole itself undergo degradation (Baveja et al., 1973; Wang et al., 1993; Baveja et al., 1975). Therefore we have also studied the kinetics of degradation of metronidazole calorimetrically. This is a rapid and general technique for the determination of both thermodynamic and kinetic parameters of chemical reactions. It's indifferent to physical state of material and thus, this technique has found its niche through the high level of sensitivity and the versatility to perform a wide range of experiments for different applications (Buckton et al., 1991; Skaria et al., 2005; Angberg et al., 1988; Beezer et al., 1999; Oliyai etal., 1991; Phipps et al., 2000; Beezer, 2001; Chadha et al., 2003a, 2003b). The major advantage of the calorimetric method over other methods for measuring the rate of decomposition of organic materials is that it is the only technique, which determines the total enthalpy change associated with the degradation process. The present study was undertaken with the aim of further exploring the potential of calorimetric technique in determining the degradation of metronidazole and its prodrug and correlate the degradation enthalpy with tentative mechanism.

\section{MATERIALS AND METHODS Materials}

Metronidazole was obtained from Rajasthan DPL, India and ciprofloxacin from Dr. Reddy's Labs., Hyderabad, India. Solvents used for synthesis and crystallization were of high purity grade and were freshly distilled before use. Buffers were prepared according to the procedure given in Indian Pharmacopoeia (TCP, 1996).

\section{Apparatus and reagents}

A C-8-calorimeter (SETARAM, France) was used to carry out calorimetric studies. Infrared and ultraviolet spectra were recorded on a Perkin-Elmer 882 infrared spectrophotometer and Perkin-Elmer 181, respectively. ${ }^{1} \mathrm{H}-\mathrm{NMR}$ were recorded on Bruker AC 300F (300MHz) equipment using trimethylsilane (TMS) as internal standard. Melting points were recorded in Veego capillary melting point apparatus in silicon oil. High sensitivity analytical balance, Mettler 433AR model was used for weighing.

\section{Preparation of 1-cyclopropyl-6-fluoro-1,4- dihydro-4-oxo-7-(1-piperazinyl)-quinoline- 3-carboxylate}

To ciprofloxacin $(2.0 \mathrm{~g}, 6.35 \mathrm{mmol})$ in tetrahydrofuran $(20 \mathrm{ml}, 277.7 \mathrm{mmol})$ thionyl chloride $(2 \mathrm{ml}, 27.6 \mathrm{mmol})$ was added. This mixture was stirred for 15 minutes. The excess of thionyl chloride was removed under pressure. The product obtained was used for the next step.

\section{Preparation of 2-(2-methyl-5- nitroimidazol-1-yl)ethyl-cyclopropyl-6- fluoro-1,4-dihydro-4-oxo-7-(1-piperazinyl)- quinoline-3-carboxylate}

The above-obtained acid chloride of ciprofloxacin (1.8 g, $5.12 \mathrm{mmol})$ was dissolved in methylene chloride $(40 \mathrm{ml})$. This solution was added drop wise to a mixture of metronidazole ( $1 \mathrm{~g}, 5.8 \mathrm{mmol})$, pyridine (1 $\mathrm{ml})$ and methylene chloride $(40 \mathrm{ml})$ under anhydrous conditions $\left(4 \mathrm{~g}\right.$ of $4 \mathrm{~A}^{0}$ molecular sieves). The resulting solution was stirred at room temperature for $25 \mathrm{~h}$. The solvent was removed in vacuo. The residue was stirred with $1 \mathrm{M}$ sodium carbonate solution $(50 \mathrm{ml})$ for 15 minutes and extracted with chloroform three times. The chloroform extract was washed with $10 \% \mathrm{w} / \mathrm{v}$ hydrochloric acid (50 $\mathrm{ml})$ and then with water $(3 \times 50 \mathrm{ml})$. The chloroform extract was dried over anhydrous sodium sulphate and solvent was evaporated in vacuo to give the desired product $(1.5 \mathrm{~g}$, $71.5 \%)$. It was recrystallized from acetone to obtain the compound, which charred at $170^{\circ} \mathrm{C}$.

$\lambda_{\max }$ (in water): $197.6 \mathrm{~nm}, 230.6 \mathrm{~nm}, 318.8 \mathrm{~nm}$

$\mathrm{R}_{\mathrm{f}}: 0.29$ in chloroform: methanol $(9.5: 0.5)$

IR(KBr): $1730 \mathrm{cms}^{-1}, 1540 \mathrm{cms}^{-1}, 1460 \mathrm{cms}^{-1}$ $1360 \mathrm{cms}^{-1}, 1260 \mathrm{cms}^{-1}, 1190 \mathrm{cms}^{-1}, 820 \mathrm{cms}^{-1}$ ${ }^{1} \mathrm{H}$ NMR $\left(\mathrm{D}_{2} \mathrm{O}\right): 1.12 \delta, 1.35 \delta, 2.42 \delta, 3.41 \delta$, $3.76 \delta, 4.36 \delta, 7.35 \delta, 7.95 \delta$ and $8.88 \delta$

\section{Microcalorimetric studies}

Heat flux microcalorimeter model C-80 (SETARAM, France) was used to study the degradation of 2-(2-methyl-5-nitroimidazol-1yl)ethyl1-cyclopropyl-6-fluoro-1,4-dihydro-4- 
oxo-7-(1-piperazinyl)-quinoline-3

carboxylate. In accordance with the Calvet principle, two experimental vessels (reference and sample) were placed in a calorimetric block. The temperature control by the thermostat of calorimeter was within \pm 0.001 $\mathrm{K}$. To carry out the study, reference cell was loaded with $5 \mathrm{ml}$ of buffer solution of desired $\mathrm{pH}$ and sample cell with a definite quantity of drug or prodrug and $5 \mathrm{ml}$ of the same buffer solution partitioned by a lid. After stabilization, mixing was done in the calorimeter itself by reversing it, which homogenizes the sample with the buffer solution. The reactions were followed for 1012 hours. The rate of heat evolution by the sample is proportional to the rate at that temperature (Chadha et al, 2003).

\section{RESULTS}

Heat evolved as a function of time has been recorded for solution of metronidazole at different concentration in the temperature range $(298.15-318.15 \mathrm{~K})$ and in aqueous solution ( $\mathrm{pH}$ range 2-10). Similar studies are carried out on its prodrug with ciprofloxacin also. The calorimetric data of heat evolution vs. time for drug $\left(14.035 \times 10^{-3} \mathrm{M}\right)$ and prodrug $\left(6.1939 \times 10^{-3} \mathrm{M}\right)$ at $\mathrm{pH} 9$ at $318.15 \mathrm{~K}$ are plotted (Figure 1).

It is assumed that total heat produced during degradation is proportional to the initial concentration of $\operatorname{drug}\left(\mathrm{q}_{0}=\mathrm{c}_{0} \mathrm{~V} \Delta_{\mathrm{r}} \mathrm{H}^{0}\right)$ for first order reaction (Beezer et al, 1999).

Here $c_{0}$ is the initial concentration of the drug, $\mathrm{V}$ is the volume of the solution taken in the calorimeter and $\Delta_{\mathrm{r}} \mathrm{H}^{0}$ is the enthalpy of degradation reaction. The heat evolved up to time

$\mathrm{q}_{\mathrm{t}}=\left(\mathrm{c}_{0}-\mathrm{c}\right) \mathrm{V} \Delta_{\mathrm{r}} \mathrm{H}^{0}=\mathrm{q}_{0}-\mathrm{cH} \Delta_{\mathrm{r}} \mathrm{H}^{0}$

Where, $\mathrm{c}=$ concentration of the drug at any time ' $\mathrm{t}$ '

It can be shown that

$\frac{\mathrm{dq}_{\mathrm{t}}}{\mathrm{dt}}=\mathrm{k}\left(\mathrm{q}_{0}-\mathrm{q}_{\mathrm{t}}\right)$

$\mathrm{dq}_{\mathrm{t}} /\left(\mathrm{q}_{0}-\mathrm{q}_{\mathrm{t}}\right)=\mathrm{kdt}$

$\ln \left(\mathrm{q}_{0}-\mathrm{q}_{\mathrm{t}}\right)=\mathrm{kt}+$ constant

$\ln \mathrm{q}_{0} /\left(\mathrm{q}_{0}-\mathrm{q}_{\mathrm{t}}\right)=\mathrm{kt}$

From the calorimetric data we know $\mathrm{q}_{\mathrm{t}}$ but due to slowness of reaction, only a small fraction of the drug degrades and therefore for determining $\mathrm{q}_{0}$ we follow the following procedure. The rate of heat evolved $\left(\mathrm{dq}_{\mathrm{t}} / \mathrm{dt}\right)$ as a function of time is related to the rate of reaction $(\Phi)$ at that time. Now by determining the $\Phi$ at two intervals $\mathrm{t}_{1}$ and $\mathrm{t}_{2}, \mathrm{q}_{0}$ was calculated.

$$
\begin{aligned}
& \text { We have at } \mathrm{t}=\mathrm{t}_{1}, \quad \Phi_{1}=\mathrm{k}\left(\mathrm{q}_{0}-\mathrm{q}_{\mathrm{t} 1}\right) \\
& \mathrm{t}=\mathrm{t}_{2}, \Phi_{2}=\mathrm{k}\left(\mathrm{q}_{0}-\mathrm{q}_{\mathrm{t} 2}\right)
\end{aligned}
$$

If $\mathrm{dq}_{\mathrm{t}} / \mathrm{dt}=\Phi_{1}=\mathrm{k}\left(\mathrm{q}_{0}-\mathrm{q}_{\mathrm{t} 1}\right)$

$$
\begin{aligned}
& \Phi_{2}=\mathrm{k}\left(\mathrm{q}_{0}-\mathrm{q}_{\mathrm{t} 2}\right) \\
& \Phi_{2} / \Phi_{1}=\mathrm{q}_{0}-\mathrm{q}_{\mathrm{t} 2} / \mathrm{q}_{0}-\mathrm{q}_{\mathrm{t} 1}
\end{aligned}
$$

or

$$
\mathrm{q}_{0}=\mathrm{q}_{\mathrm{t} 1}+\frac{\mathrm{q}_{\mathrm{t} 1}-\mathrm{q}_{\mathrm{t} 2}}{\Phi_{2} / \Phi_{1}-1} \quad \ldots \ldots .1
$$

where

$\mathrm{q}_{0}=$ total heat evolved in degradation reaction starting with $\mathrm{V}$ litre of solution with initial concentration $\left(\mathrm{c}_{0}\right)$

$\mathrm{q}_{\mathrm{t} 1}=$ heat evolved up to time $\mathrm{t}_{1}$

$\mathrm{q}_{\mathrm{t} 2}=$ heat evolved up to time $\mathrm{t}_{2}$

$\Phi_{1}=$ rate of heat evolved at $t_{1}$

$\Phi_{2}=$ rate of heat evolved at $t_{2}$

and $\Delta_{r} \mathrm{H}^{0}=\mathrm{q}_{0} / \mathrm{c}_{0} \mathrm{~V} \quad \ldots \ldots \ldots \ldots \ldots .2$

The $\mathrm{q}_{0}$ is estimated using equation 1. Table 1 gives value of heat evolved up to various interval of time for drug (7.0175 x $10^{-5}$ moles) and prodrug $\left(3.09695 \times 10^{-5}\right.$ moles $)$ at $\mathrm{pH} 8$ and temperature $318.15 \mathrm{~K}$. The values for $\mathrm{q}_{0}$ have been calculated to be $14.036 \mathrm{~J}$ and 4.345 $\mathrm{J}$, respectively. The enthalpies of reaction $\left(\Delta_{\mathrm{r}} \mathrm{H}^{0}\right)$ calculated from the $\left(\mathrm{q}_{0}\right)$ total heat evolved at various concentrations and $\mathrm{pH}$ for both drug and prodrug at different temperatures are given in tables 2, 3 and 4. It can be seen that the value differs slightly with $\mathrm{pH}$ and temperature but is otherwise in excellent agreement with each other for two different initial concentrations of the drug. It may be noted that $\mathrm{q}_{0}$ is proportional to initial concentration of the drug where $\left(q_{0}-q_{t}\right)$ is proportional to concentration of the drug at time t. For the first order reaction the rate constant is given by the equation

$$
\ln \mathrm{q}_{0}-\ln \left(\mathrm{q}_{0}-\mathrm{q}_{\mathrm{t}}\right)=\mathrm{kt}
$$

or

$$
\mathrm{k}=\frac{1}{\mathrm{t}} \ln \frac{\mathrm{q}_{0}}{\mathrm{q}_{0}-\mathrm{q}_{\mathrm{t}}}
$$


The plots between $\ln \left(\mathrm{q}_{0}-\mathrm{q}_{\mathrm{t}}\right)$ against $\mathrm{t}$ are straight lines (Figure 2) at various concentrations and $\mathrm{pH}$. The values of first order rate constant, $\mathrm{k}$, calculated from the slope of the straight line plot at different concentration, $\mathrm{pH}$ and temperature for drug and prodrug are given in table 2, 3 and 4 .

The effect of $\mathrm{pH}$ on the degradation of metronidazole in aqueous solution at constant ionic strength $(0.2)$ and at $37^{\circ} \mathrm{C}$ is shown in plots of $\log \mathrm{k}$ vs $\mathrm{pH}$ (Figure 3). The temperature dependence of metronidazole and prodrug were studied at all the $\mathrm{pH}$ in the temperature range 303.15 to $318.15 \mathrm{~K}$. The investigation is aimed to determine the optimum $\mathrm{pH}$ for the maximum stability. An Arrhenius plot of $\log$ of $\mathrm{k}$ vs reciprocal of temperature is given in Figure 4.

\section{DISCUSSION}

The values of $k$, the rate constant calculated from the slope of plot of $\ln \left(q_{0}-q_{t}\right)$ vs $t$ (Tables 2, 3 and 4), for two concentrations at a particular $\mathrm{pH}$ and temperature indicate that the degradation follows pseudo first order kinetics for drug as well as prodrug. The absolute value of rate constant for decomposition changes with $\mathrm{pH}$. Metronidazole has one ionizable group with a $\mathrm{pKa}$ value of 2.5. It was found that the results at different $\mathrm{pH}$ are in agreement with the following equation:

$$
\mathrm{K}_{\mathrm{obs}}=\left\{\mathrm{k}_{\mathrm{H}}\left[\mathrm{H}^{+}\right]+\mathrm{k}_{\mathrm{up}}+\mathrm{k}_{\mathrm{OH}}\left[\mathrm{OH}^{-}\right]\right\} \mathrm{f}^{\mathrm{up}}
$$$$
\text { .......4 }
$$

Where $\mathrm{f}^{\mathrm{up}}$ is the fraction of unprotonated species at a particular $\mathrm{pH}$ and the values have been given in Table 5 . The experimental $\mathrm{k}_{\mathrm{obs}}$ are compared with those calculated from the above equations and presented in the table 2, 3 and 4. It can be seen that there is good agreement at all the $\mathrm{pH}$. The first order rate constant for solvent assisted degradation is represented by $\mathrm{k}_{\text {up }}$ while $\mathrm{k}_{\mathrm{OH}}$ is the second order rate constants for base catalyzed degradation. The degradation of metronidazole followed a first order reaction in both acidic and alkaline conditions and exhibited maximum stability at $\mathrm{pH}$ 4-6. This trend is in agreement with the earlier results published by Wang and Yeh (1993). However, direct comparison of the rate constants could not be made as the authors

have studied the degradation kinetics under accelerated conditions.

The degradation of metronidazole below pH 3 is described by catalytic effect of specific acid and water. The figure 3 shows that there is no inflection point in the $\mathrm{pH}$ vs rate constant of the reaction thus predicting to be a $\mathrm{H}^{+}$and $\mathrm{OH}^{-}$catalyzed reaction. Not much data is available in literature about the degradation products. However, Salo and Solmies (1996) have shown the formation of ethylene diamine and corresponding acid with the breaking of the ring at higher $\mathrm{pH}$. At mild $\mathrm{pH}$, the degradation is governed by solvent assisted degradation while in alkaline condition there is reaction between unprotonated metronidazole and $\mathrm{OH}^{-}$. Study by Baveja and Khosla (1975) has shown the formation of amine at lower $\mathrm{pH}$ also. There is a possibility that at lower $\mathrm{pH}$ the drug decomposes and looses its nitroimidazole structure. Calorimetric technique used in this study supports this hypothesis by comparing

Table 1: Heat evolved $\left(\mathrm{q}_{\mathrm{t}}\right)$ at various time intervals $(\mathrm{T})$ for metronidazole $\left(7.0175 \times 10^{-5}\right.$ moles in $5 \mathrm{ml})$ and its prodrug (3.09695 $\times 10^{-5}$ moles in $5 \mathrm{ml}$ ) at $\mathrm{pH} 8$ and $318.15 \mathrm{~K}$

\begin{tabular}{|c|c|c|c|c|}
\hline \multirow[t]{2}{*}{$T\left(\min ^{-1}\right)$} & \multicolumn{2}{|c|}{$10^{2} \times \mathrm{q}_{\mathrm{t}}(\mathrm{J})$} & \multicolumn{2}{|c|}{$\ln \left(\mathrm{q}_{0}-\mathrm{q}_{\mathrm{t}}\right)$} \\
\hline & Drug & Prodrug & Drug & Prodrug \\
\hline 30 & 0.630 & 6.394 & 2.641 & 1.454 \\
\hline 60 & 1.260 & 13.673 & 2.641 & 1.437 \\
\hline 120 & 2.519 & 26.909 & 2.640 & 1.405 \\
\hline 240 & 5.032 & 52.146 & 2.638 & 1.341 \\
\hline 420 & 8.795 & 87.105 & 2.635 & 1.245 \\
\hline 510 & 10.671 & 103.368 & 2.634 & 1.197 \\
\hline 600 & 12.547 & 118.870 & 2.633 & 1.149 \\
\hline 720 & 15.043 & 134.568 & 2.631 & 1.098 \\
\hline 840 & 17.535 & 156.756 & 2.629 & 1.021 \\
\hline 960 & 20.022 & 173.959 & 2.627 & 0.958 \\
\hline
\end{tabular}




\section{R. CHADHA et al. / Int. J. Biol. Chem. Sci. 1(3): 197-210, 2007}

Table 2: Kinetic parameters of degradation of metronidazole and its prodrug at $303.15 \mathrm{~K}$.

\begin{tabular}{|c|c|c|c|c|c|c|c|c|c|c|c|c|}
\hline \multirow[t]{2}{*}{$\mathrm{pH}$} & \multicolumn{2}{|c|}{$10^{3}$ X Conc. (M) } & \multicolumn{2}{|c|}{$\Delta_{\mathrm{r}} \mathrm{H}^{0}\left(\mathrm{~kJ} \mathrm{~mol}^{-1}\right)$} & \multicolumn{2}{|c|}{$\mathrm{q}_{0}(\mathrm{~J})$} & \multicolumn{2}{|c|}{$\begin{array}{c}10^{4} \times \mathrm{k}\left(\mathrm{h}^{-1}\right) \\
\text { Experimental }\end{array}$} & \multicolumn{2}{|c|}{$\begin{array}{c}\left.10^{4} \times \mathrm{K}^{-1} \mathrm{~h}^{-1}\right) \\
\text { Calculated }\end{array}$} & \multicolumn{2}{|c|}{$\mathrm{t}_{1 / 2}(\mathrm{hrs})$} \\
\hline & Drug & Prodrug & Drug & Prodrug & Drug & Prodrug & Drug & Prodrug & Drug & Prodrug & Drug & Prodrug \\
\hline \multirow[t]{2}{*}{2} & 8.187 & 3.3034 & 222.92 & 129.56 & 9.12 & 2.14 & 3.670 & 164.94 & 3.580 & 164.89 & 1946.64 & 42.02 \\
\hline & 14.03 & 6.1939 & 222.82 & 129.81 & 15.64 & 4.02 & 3.630 & 164.70 & & & 1985.76 & 42.08 \\
\hline \multirow{2}{*}{3} & 8.187 & 3.3034 & 205.41 & 132.49 & 8.41 & 2.19 & 1.899 & 103.70 & 1.932 & 103.79 & 3664.80 & 49.49 \\
\hline & 14.035 & 6.1939 & 205.22 & 132.39 & 14.40 & 4.11 & 1.897 & 103.84 & & & 3676.32 & 66.74 \\
\hline \multirow{2}{*}{4} & 8.187 & 3.3034 & 211.09 & 136.89 & 8.64 & 2.27 & 1.244 & 84.6284 .99 & 1267 & 847 & 5570.64 & 80.64 \\
\hline & 14.035 & 6.1939 & 211.39 & 136.91 & 14.83 & 4.24 & 1.248 & 81.8881 .91 & 1.267 & 84.1 & 5552.88 & 81.49 \\
\hline \multirow{2}{*}{5} & 8.187 & 3.3034 & 215.14 & 141.18 & 8.81 & 2.33 & 1.15 & 82.9182 .95 & & & 6041.76 & 84.64 \\
\hline & 14.035 & 6.1939 & 214.97 & 140.95 & 15.09 & 4.37 & 1.15 & 90.2590 .25 & 1.181 & 82.33 & 6020.88 & 84.60 \\
\hline \multirow{2}{*}{6} & 8.187 & 3.3034 & 216.38 & 144.58 & 8.86 & 2.39 & 1.17 & 186.49 & & & 5928.24 & 83.58 \\
\hline & 14.035 & 6.1939 & 216.89 & 144.34 & 15.22 & 4.48 & 1.17 & 186.53 & 1.189 & 83.00 & 5912.88 & 83.54 \\
\hline \multirow{2}{*}{7} & 8.187 & 3.3034 & 217.41 & 148.21 & 8.90 & 2.45 & 1.361 .35 & 1107.0 & & & 5099.28 & 76.79 \\
\hline & 14.035 & 6.1939 & 217.16 & 148.02 & 15.24 & 4.58 & 3.19 & 1107.84 & 1.352 & 92.20 & 5118.24 & 76.79 \\
\hline \multirow{3}{*}{8} & 8.187 & 3.3034 & 211.77 & 148.33 & 8.67 & 2.45 & 3.21 & & & & 2171.76 & 37.16 \\
\hline & 14.035 & 6.1939 & 211.50 & 148.50 & 14.84 & 4.60 & 21.57 & & 3.208 & 184.4 & 2162.16321 .36 & 37.156 .26 \\
\hline & 8.187 & 3.3034 & 205.19 & 149.38 & 8.40 & 2.72 & 21.48 & & 5.200 & 104.4 & 322.56 & 6.25 \\
\hline 9 & 14.035 & 6.1939 & 205.08 & 149.79 & 14.39 & 4.67 & & & 21.55 & 1106.46 & & \\
\hline
\end{tabular}

$\Delta_{\mathrm{r}} \mathrm{H}^{0}=$ Enthalpy of reaction; $\mathrm{q}_{0}=$ Total heat evolved; $\mathrm{k}=$ rate constant 


\section{R. CHADHA et al. / Int. J. Biol. Chem. Sci. 1(3): 197-210, 2007}

Table 3: Kinetic parameters of degradation of metronidazole and its prodrug at $310.15 \mathrm{~K}$.

\begin{tabular}{|c|c|c|c|c|c|c|c|c|c|c|c|c|}
\hline \multirow[t]{2}{*}{$\mathrm{pH}$} & \multicolumn{2}{|c|}{$10^{3}$ X Conc. $(\mathrm{M})$} & \multicolumn{2}{|c|}{$\Delta_{\mathrm{r}} \mathrm{H}^{0}\left(\mathrm{~kJ} \mathrm{~mol}^{-1}\right)$} & \multicolumn{2}{|c|}{$\mathrm{q}_{0}(\mathrm{~J})$} & \multicolumn{2}{|c|}{$\begin{array}{c}10^{4}{\mathrm{X} \mathrm{k}\left(\mathrm{h}^{-1}\right)} \\
\text { Experimental }\end{array}$} & \multicolumn{2}{|c|}{$\begin{array}{c}10^{4} \times \mathrm{k}\left(\mathrm{h}^{-1}\right) \\
\text { Calculated }\end{array}$} & \multicolumn{2}{|c|}{$\mathrm{t} 1 / 2(\mathrm{hrs})$} \\
\hline & Drug & Prodrug & Drug & Prodrug & Drug & Prodrug & Drug & Prodrug & Drug & Prodrug & Drug & Prodrug \\
\hline \multirow[t]{2}{*}{2} & 8.187 & 3.3034 & 219.97 & 124.08 & 9.00 & 2.05 & 6.448 & 217.46 & 6.594 & 217.63 & 1035.87 & 31.87 \\
\hline & 14.035 & 6.1939 & 220.43 & 126.41 & 15.47 & 3.27 & 6.522 & 217.57 & & & 1062.88 & 31.85 \\
\hline \multirow[t]{2}{*}{3} & 8.187 & 3.3034 & 200.44 & 128.54 & 8.21 & 2.12 & 3.385 & 138.32 & 3.486 & 138.38 & 2093.04 & 50.10 \\
\hline & 14.035 & 6.1939 & 200.84 & 128.42 & 14.09 & 3.98 & 3.420 & 138.47 & & & 2026.32 & 50.05 \\
\hline \multirow[t]{2}{*}{4} & 8.187 & 3.3034 & 200.20 & 133.91 & 8.19 & 2.21 & 2.165 & 113.69 & 2.233 & 113.74 & 3192.00 & 60.98 \\
\hline & 14.035 & 6.1939 & 205.08 & 134.25 & 14.39 & 4.16 & 2.163 & 113.77 & & & 3174.48 & 60.91 \\
\hline \multirow[t]{2}{*}{5} & 8.187 & 3.3034 & 208.16 & 136.88 & 8.52 & 2.26 & 1.980 & 110.21 & 2.072 & 110.69 & 3499.92 & 62.88 \\
\hline & 14.035 & 6.1939 & 209.87 & 136.71 & 14.73 & 4.23 & 1.982 & 110.20 & & & 3496.56 & 62.89 \\
\hline \multirow[t]{2}{*}{6} & 8.187 & 3.3034 & 209.53 & 140.56 & 8.58 & 2.32 & 2.021 & 111.32 & 2.085 & 111.53 & 3430.80 & 62.25 \\
\hline & 14.035 & 6.1939 & 209.63 & 140.53 & 14.71 & 4.35 & 2.079 & 111.45 & & & 3331.68 & 62.18 \\
\hline \multirow[t]{2}{*}{7} & 8.187 & 3.3034 & 211.01 & 143.44 & 8.64 & 2.37 & 2.292 & 122.78 & 2.337 & 123.15 & 3026.16 & 56.44 \\
\hline & 14.035 & 6.1939 & 210.78 & 143.51 & 14.79 & 4.44 & 2.338 & 123.68 & & & 2961.60 & 56.03 \\
\hline \multirow[t]{2}{*}{8} & 8.187 & 3.3034 & 204.57 & 144.70 & 18.37 & 2.40 & 5.15 & 239.65 & 5.292 & 239.68 & 1345.92 & 28.92 \\
\hline & 14.035 & 6.1939 & 205.00 & 145.17 & 14.39 & 4.50 & 5.24 & 240.11 & & & 1323.60 & 28.86 \\
\hline \multirow[t]{2}{*}{9} & 8.187 & 3.3034 & 198.81 & 145.85 & 8.14 & 2.41 & 34.162 & 1405.56 & 34.47 & 1405.0 & 202.80 & 4.934 .93 \\
\hline & 14.035 & 6.1939 & 199.11 & 146.91 & 13.97 & 4.5 & 34.778 & 1405.38 & & & 199.20 & \\
\hline
\end{tabular}

$\Delta_{\mathrm{r}} \mathrm{H}^{0}=$ Enthalpy of reaction; $\mathrm{q}_{0}=$ Total heat evolved; $\mathrm{k}=$ rate constant 
Table 4: Kinetic parameters of degradation of metronidazole and its prodrug at $318.15 \mathrm{~K}$.

\begin{tabular}{|c|c|c|c|c|c|c|c|c|c|c|c|c|}
\hline \multirow[t]{2}{*}{$\mathrm{pH}$} & \multicolumn{2}{|c|}{$10^{3}$ X Conc. $(\mathrm{M})$} & \multicolumn{2}{|c|}{$\Delta_{\mathrm{r}} \mathrm{H}^{0}\left(\mathrm{~kJ} \mathrm{~mol}^{-1}\right)$} & \multicolumn{2}{|c|}{$\mathrm{q}_{0}(\mathrm{~J})$} & \multicolumn{2}{|c|}{$\begin{array}{c}10^{4} \mathrm{X} \mathrm{k}\left(\mathrm{h}^{-1}\right) \\
\text { Experimental }\end{array}$} & \multicolumn{2}{|c|}{$\begin{array}{c}10^{4} \times \mathrm{k}\left(\mathrm{h}^{-1}\right) \\
\text { Calculated }\end{array}$} & \multicolumn{2}{|c|}{$\mathrm{t} 1 / 2(\mathrm{hrs})$} \\
\hline & Drug & Prodrug & Drug & Prodrug & Drug & Prodrug & Drug & Prodrug & Drug & Prodrug & Drug & Prodrug \\
\hline \multirow[t]{2}{*}{2} & 8.187 & 3.3034 & 217.31 & 123.51 & 8.89 & 2.044 & 10.922 & 294.04 & 10.828 & 293.86 & 637.593 & 23.568 \\
\hline & 14.035 & 6.1939 & 217.26 & 124.39 & 15.25 & 3.852 & 10.934 & 293.58 & & & 642.261 & 23.605 \\
\hline \multirow[t]{2}{*}{3} & 8.187 & 3.3034 & 196.33 & 126.54 & 8.04 & 2.091 & 5.796 & 189.46 & 5.980 & 189.47 & 1361.28 & 36.577 \\
\hline & 14.035 & 6.1939 & 197.21 & 126.65 & 13.84 & 3.922 & 5.798 & 189.48 & & & 1353.6 & 36.551 \\
\hline \multirow[t]{2}{*}{4} & 8.187 & 3.3034 & 202.89 & 126.31 & 8.31 & 2.158 & 3.901 & 158.02 & 4.0257 & 157.11 & 1753.2 & 43.58 \\
\hline & 14.035 & 6.1939 & 202.79 & 130.41 & 14.23 & 4.039 & 3.894 & 156.14 & & & 1781.52 & 44.948 \\
\hline \multirow[t]{2}{*}{5} & 8.187 & 3.3034 & 204.62 & 139.83 & 8.38 & 2.309 & 3.620 & 152.43 & 3.774 & 153.1 & 1912.8 & 45.463 \\
\hline & 14.035 & 6.1939 & 204.79 & 134.57 & 14.37 & 4.167 & 3.620 & 152.50 & & & 1963.2 & 45.442 \\
\hline \multirow[t]{2}{*}{6} & 8.187 & 3.3034 & 205.75 & 136.83 & 8.42 & 2.260 & 3.711 & 154.16 & 3.789 & 154.17 & 1867.92 & 44.95 \\
\hline & 14.035 & 6.1939 & 205.81 & 134.26 & 14.44 & 4.159 & 3.770 & 154.11 & & & 1838.16 & 44.967 \\
\hline \multirow[t]{2}{*}{7} & 8.187 & 3.3034 & 206.61 & 144.13 & 8.46 & 2.381 & 4.062 & 166.04 & 4.267 & 169.09 & 1706.88 & 41.735 \\
\hline & 14.035 & 6.1939 & 206.76 & 139.16 & 14.51 & 4.309 & 4.518 & 171.04 & & & 1533.12 & 40.516 \\
\hline \multirow[t]{2}{*}{8} & 8.187 & 3.3034 & 199.50 & 140.59 & 8.17 & 2.322 & 8.667 & 320.09 & 9.001 & 318.69 & 799.2771 .6 & 21.656 \\
\hline & 14.035 & 6.1939 & 200.02 & 140.29 & 14.04 & 4.345 & 8.984 & 318.58 & & & 122.88 & 21.753 \\
\hline \multirow[t]{2}{*}{9} & 8.187 & 3.3034 & 194.14 & 142.88 & 7.95 & 2.366 & 56.350 & 1794.4 & 56.35 & 1814.8 & 121.68 & 3.862 \\
\hline & 14.035 & 6.1939 & 194.45 & 140.90 & 13.65 & 4.364 & 56.920 & 1835.3 & & & & 3.7393 \\
\hline
\end{tabular}

$\Delta_{\mathrm{r}} \mathrm{H}^{0}=$ Enthalpy of reaction; $\mathrm{q}_{0}=$ Total heat evolved; $\mathrm{k}=$ rate constant 
Table 5: Fraction of different species of metronidazole and its prodrug at different $\mathrm{pH}$

\begin{tabular}{|c|c|c|c|c|c|}
\hline pH & $\mathbf{f}^{\mathbf{p}}$ & $\mathbf{f}^{\mathrm{uP}}$ & $\mathbf{f}^{\mathbf{p p}}$ & $\mathbf{f}^{\mathbf{P}}$ & $\mathbf{f}^{\mathrm{uP}}$ \\
\hline \multicolumn{3}{|c|}{ Drug } & \multicolumn{3}{|c|}{ Prodrug } \\
\hline 2 & 0.7597 & 0.2403 & 0.7597 & 0.2403 & $3.808 \times 10^{-8}$ \\
\hline 3 & 0.2403 & 0.7597 & 0.2403 & 0.7597 & $1.204 \times 10^{-6}$ \\
\hline 4 & 0.0307 & 0.9693 & 0.03065 & 0.9693 & $1.536 \times 10^{-5}$ \\
\hline 5 & 0.0032 & 0.9968 & 0.00315 & 0.99669 & 0.00016 \\
\hline 6 & 0.0003 & 0.9997 & 0.00032 & 0.99810 & 0.00158 \\
\hline 7 & - & - & $3.1128 \times 10^{-5}$ & 0.98437 & 0.01560 \\
\hline 8 & - & - & $2.7296 \times 10^{-6}$ & 0.86319 & 0.13681 \\
\hline 9 & - & - & $1.2234 \times 10^{-7}$ & 0.38686 & 0.61314 \\
\hline
\end{tabular}

$\mathrm{f}^{\mathrm{pp}}=$ fraction of the total prodrug when both nitrogens are unprotonated.

Table 6: Calculated value of overall enthalpy change

\begin{tabular}{|c|c|c|c|}
\hline Total bond broken & Enthalpy (kJ mol $\left.{ }^{-1}\right)$ & Bond form & Enthalpy $\left(\mathrm{kJ} \mathrm{mol}^{-1}\right)$ \\
\hline One $\mathrm{H}_{2} \mathrm{C}-\mathrm{O}$ & 426.36 & One N-H & 351.12 \\
\hline One $\mathrm{N}=\mathrm{C}$ & 936.32 & One NH-H & 372.02 \\
\hline One HO-H & 497.42 & One $\mathrm{H}-\mathrm{NC}$ & 351.12 \\
\hline One $\mathrm{C}-\mathrm{N}$ & 330.22 & One $\mathrm{OH}$ bond attached to $\mathrm{CH}_{3}$ & 334.40 \\
\hline \multirow[t]{3}{*}{ Total } & 2190.32 & One $\mathrm{C}=\mathrm{O}$ & 1070.08 \\
\hline & & Total & 2478.74 \\
\hline & \multicolumn{3}{|c|}{ Therefore overall enthalpy $=-288.42 \mathrm{~kJ} \mathrm{~mol}^{-1}$} \\
\hline
\end{tabular}

Table 7: Various rate constants for the degradation of metronidazole and prodrug

\begin{tabular}{|c|c|c|c|c|}
\hline Temperature & $k_{H}\left(M^{-1} h^{-1}\right)$ & $\mathbf{K}_{\mathrm{p}}\left(\mathbf{h}^{-1}\right)$ & $K_{\text {up }}\left(h^{-1}\right)$ & $\mathbf{k}_{\mathrm{OH}}\left(\mathbf{M}^{-1} \mathbf{h}^{-1}\right)$ \\
\hline \multicolumn{5}{|c|}{ Drug } \\
\hline 303.15 & 0.1373 & - & 0.000117 & 203.8 \\
\hline 310.15 & 0.2539 & - & 0.000205 & 324.4 \\
\hline 318.15 & 0.4132 & - & 0.000374 & 526.1 \\
\hline \multicolumn{5}{|c|}{ Prodrug } \\
\hline 303.15 & 0.2032 & 0.01708 & 0.008195 & 10245.1 \\
\hline 310.15 & 0.2681 & 0.02248 & 0.01102 & 12948 \\
\hline 318.15 & 0.3569 & 0.03024 & 0.015246 & 16623.4 \\
\hline
\end{tabular}

$\mathrm{k}_{\mathrm{p}}$ and $\mathrm{k}_{\mathrm{up}}=$ first order rate constants for solvent assisted degradation; $\mathrm{k}_{\mathrm{H}}=$ second order rate constant for acid catalyzed degradation; $\mathrm{k}_{\mathrm{OH}}=$ second order rate constant for base catalyzed degradation .

the enthalpy of reaction at various $\mathrm{pH}$ (Tables 2, 3 and 4). Much higher value of degradation enthalpy at lower $\mathrm{pH}$ indicates the decomposition of the drug. We have tried to correlate our enthalpy of reaction with the tentative mechanism. According to the figure 5 certain bonds are broken while new bonds are formed leading to the exothermic enthalpy of reaction (Table 6). The calculated value has been found to be 288.42 , which agrees well with the molar enthalpy of degradation (222.92-203 over $\mathrm{pH}$ 2-9).

The rate of hydrolytic reaction leading to the liberation of metronidazole and ciprofloxacin from mutual prodrug of metronidazole is much higher as compared to the degradation of metronidazole (Tables 2, 3 and 4). The observation of significantly higher value of rate constant is an evidence for the operation of intramolecular catalysis assisted by keto group on the ciprofloxacin as shown in Figure 6 (Bowden, 1995). Therefore under the experimental conditions the enthalpy involved in the hydrolysis of prodrug does not involve the enthalpy associated with the degradation of metronidazole. Literature survey has revealed that ciprofloxacin is also stable over this $\mathrm{pH}$ range. Tables 2, 3 and 4 indicate that the hydrolysis of the prodrug is also $\mathrm{pH}$ dependent and can be accounted for 
Table 8: Activation parameters for the overall degradation reaction and individual rate constants of metronidazole and its prodrug over the $\mathrm{pH}$ range 2-9.

\begin{tabular}{|c|c|c|c|c|c|c|c|c|c|c|}
\hline pH & \multicolumn{2}{|c|}{$E_{a}\left(k^{\prime} ~ m o l^{-1}\right)$} & \multicolumn{2}{|c|}{$\ln A\left(h^{-1}\right)$} & \multicolumn{2}{|c|}{$\Delta \mathrm{G}^{\ddagger}\left(\mathrm{kJ} \mathrm{mol}^{-1}\right)$} & \multicolumn{2}{|c|}{$\Delta \mathrm{S}^{\ddagger}\left(\mathrm{J} \mathrm{mol}^{-1} \mathrm{~K}^{-1}\right)$} & \multicolumn{2}{|c|}{$\Delta \mathrm{H}^{\ddagger}\left(\mathrm{kJ} \mathrm{mol}^{-1}\right)$} \\
\hline & Drug & Prodrug & Drug & Prodrug & Drug & Prodrug & Drug & Prodrug & Drug & Prodrug \\
\hline 2 & 59.05 & 30.81 & 15.52 & 15.029 & 132.33 & 105.28 & -188.76 & -245.648 & 57.63 & 30.80 \\
\hline 3 & 53.24 & 32.03 & 12.58 & 15.05 & 133.96 & 106.43 & -210.586 & -245.449 & 52.69 & 32.025 \\
\hline 4 & 61.28 & 32.26 & 15.32 & 14.945 & 134.99 & 106.93 & -184.34 & -246.333 & 60.958 & 32.250 \\
\hline 5 & 60.70 & 33.13 & 15.01 & 15.25 & 135.20 & 107.03 & -188.35 & -243.811 & 61.183 & 33.123 \\
\hline 6 & 62.09 & 33.05 & 15.59 & 15.226 & 135.15 & 107.00 & -183.59 & -243.98 & 61.440 & 33.039 \\
\hline 7 & 61.58 & 33.23 & 15.52 & 15.39 & 134.78 & 106.79 & $\begin{array}{l}-184.08 \\
\end{array}$ & -242.674 & 60.642 & 33.223 \\
\hline 8 & 54.26 & 28.67 & 13.48 & 14.298 & 132.62 & 104.96 & -201.06 & -251.695 & 53.059 & 28.658 \\
\hline 9 & 51.70 & 26.59 & 14.38 & 15.258 & 127.81 & 100.47 & -193.65 & -243.742 & 51.480 & 26.579 \\
\hline \multicolumn{11}{|c|}{ Individual rate constants } \\
\hline $\mathrm{k}_{\mathrm{H}}$ & 58.76 & 30.10 & 21.36 & 10.35 & 117.34 & 116.35 & -135.81 & -227.11 & 58.757 & 30.09 \\
\hline $\mathrm{k}_{\mathrm{p}}$ & - & 30.62 & - & 8.08 & - & 122.59 & - & -245.97 & - & 30.62 \\
\hline $\mathrm{k}_{\mathrm{up}}$ & 62.11 & 33.19 & 15.59 & 8.36 & 135.15 & 124.44 & -183.52 & -243.62 & 62.106 & 33.18 \\
\hline $\mathrm{k}_{\mathrm{OH}}$ & 50.68 & 25.87 & 25.43 & 19.50 & 98.93 & 89.06 & -101.76 & -151.04 & 50.673 & 25.86 \\
\hline
\end{tabular}

$\mathrm{k}_{\mathrm{p}}$ and $\mathrm{k}_{\mathrm{up}}=$ first order rate constants for solvent assisted degradation; $\mathrm{k}_{\mathrm{H}}=$ second order rate constant for acid catalyzed degradation; $\mathrm{k}_{\mathrm{OH}}=$ second order rate constant for base catalyzed degradation; $E_{a}=$ free energy of activation; $\ln A=$ frequency factor; $\Delta G^{\ddagger}=$ free energy of activation; $\Delta \mathrm{S}^{\ddagger}=$ entropy of activation; $\Delta \mathrm{H}^{\ddagger}=$ enthalpy of activation

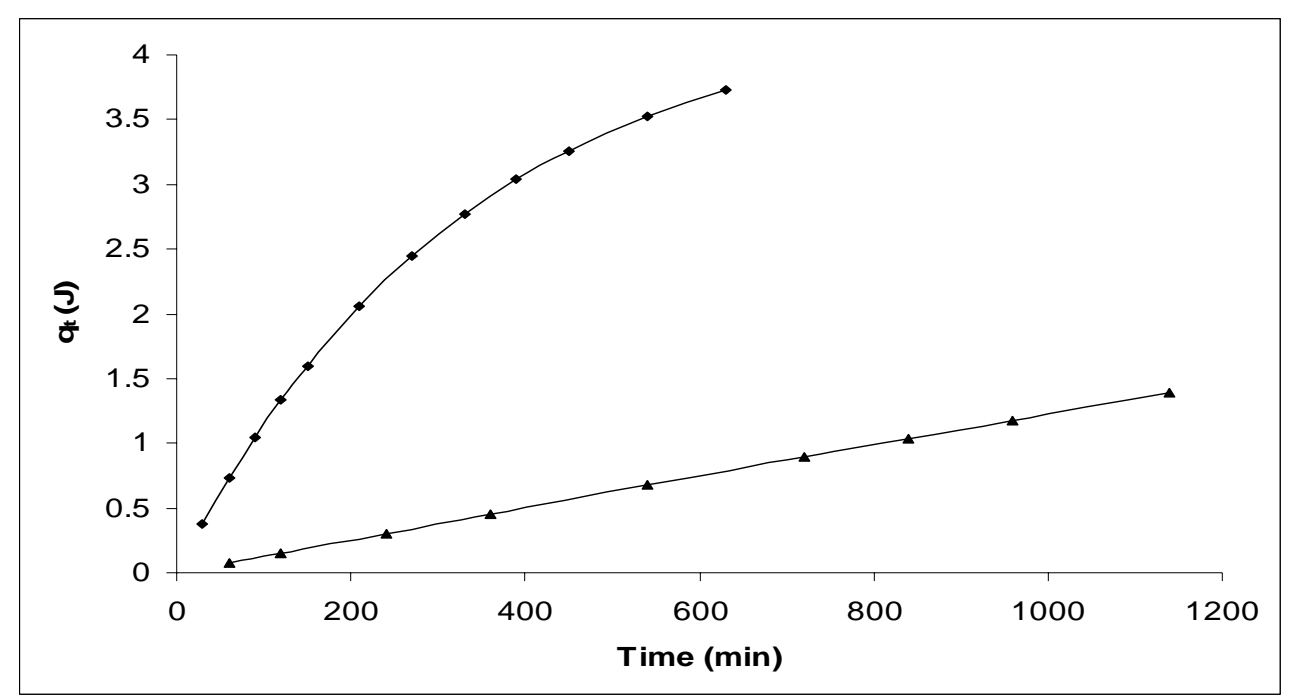

Figure 1: Calorimetric data of heat evolution (qt) vs time for degradation of metronidazole and its prodrug at $\mathrm{pH} 9$ at $318.15 \mathrm{~K}$. (Drug $(\boldsymbol{\Lambda})$, prodrug $(\bullet))$.

by general acid/base catalysis at different temperatures. The influence of $\mathrm{pH}$ on the rate of hydrolysis at $37^{\circ} \mathrm{C}$ is shown in figure 3 in which the logarithm of the pseudo first order rate constants $\left(\mathrm{k}_{\mathrm{obs}}\right)$ is plotted against $\mathrm{pH}$. For the prodrug the stability occurs at $\mathrm{pH}$ values about 4-6 characteristic of general acid/base catalysis. In the $\mathrm{pH}$ region investigated the prodrug occurs in three forms with the nitrogen in imidazoline ring as well as nitrogen in piperazine ring in protonated and unprotonated forms. The shape of the $\mathrm{pH}$ rate profile indicates that the unprotonated and protonated nitrogen forms of prodrug undergo hydrolysis at different rates. The hydrolysis can be described in terms of specific reactions involving both species and a spontaneous and specific acid and base catalyzed reaction.

The best agreement at all the $\mathrm{pH}$ was obtained from the following equation: 


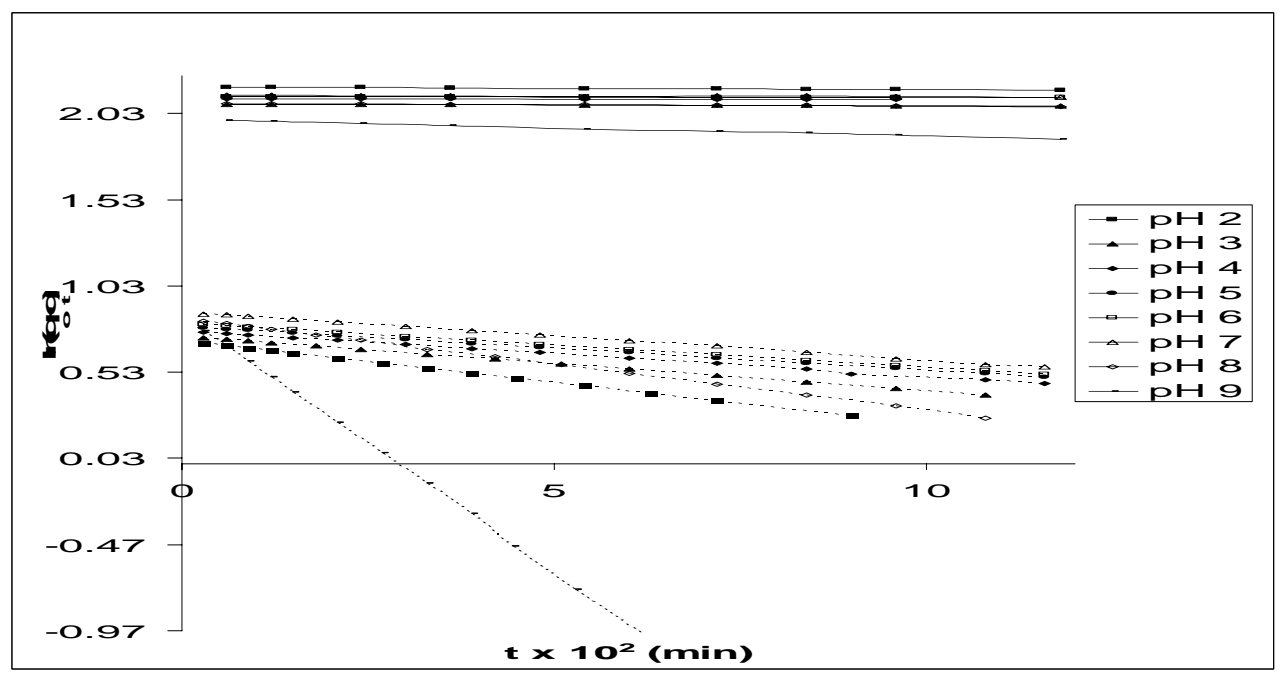

Figure 2: First order plot of degradation of metronidazole $(-)\left(8.187 \times 10^{-3} \mathrm{M}\right)$ and its prodrug (--) $\left(3.3034 \times 10^{-3} \mathrm{M}\right)$ over the range of $\mathrm{pH} 2-9$ at $318.15 \mathrm{~K}$.

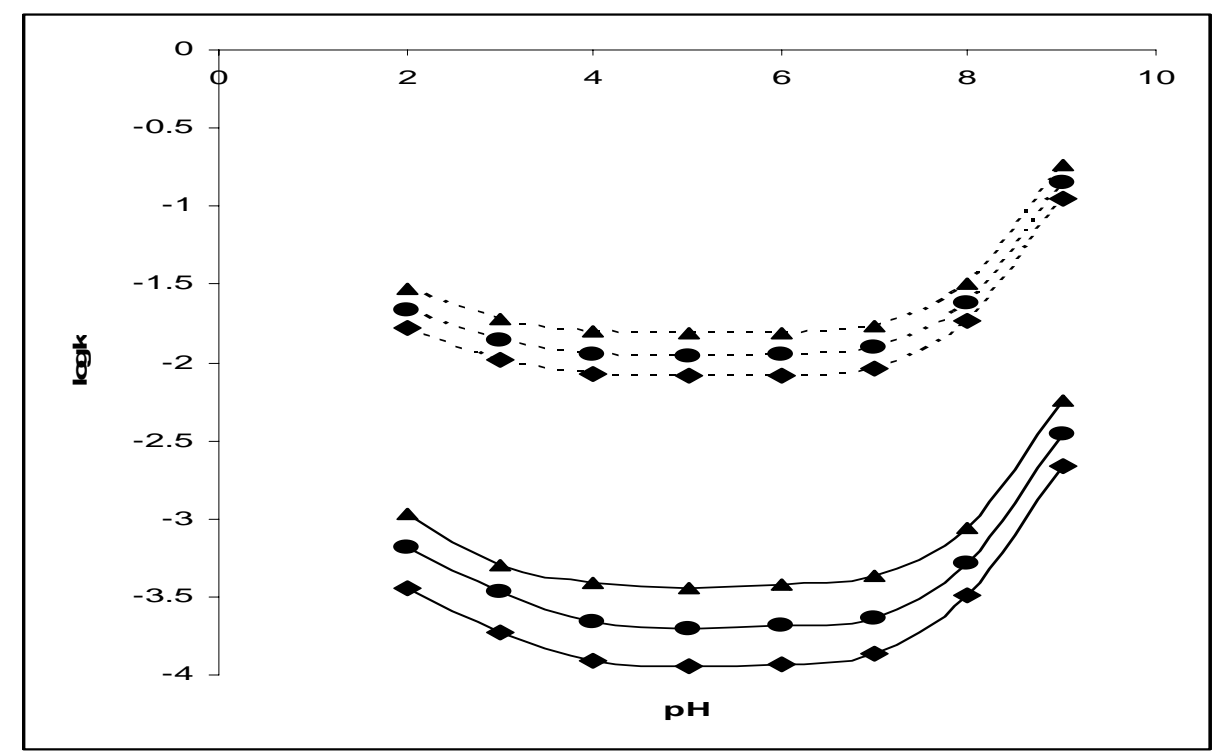

Figure 3: Plot of $\log \mathrm{k}$ vs $\mathrm{pH}$ profile in the temperature range of 303.15-318.15 K. Solid lines represent the drug and broken lines the prodrug $(303.15(\bullet), 310.15(\bullet), 318.15(\mathbf{\Lambda}))$

$$
\mathrm{k}_{\mathrm{obs}}=\mathrm{k}_{\mathrm{H}}\left[\mathrm{H}^{+}\right] \mathrm{f}^{\mathrm{pp}}+\mathrm{k}_{\mathrm{p}} \mathrm{f}^{\mathrm{pp}}+\mathrm{k}_{\mathrm{up}}\left(\mathrm{f}^{\mathrm{p}}+\mathrm{f}^{\mathrm{up}}\right)+\mathrm{k}_{\mathrm{OH}}\left[\mathrm{OH}^{-}\right]\left(\mathrm{f}^{\mathrm{p}}+\mathrm{f}^{\mathrm{up}}\right)
$$

$\mathrm{f}^{\mathrm{pp}}=$ fraction of the total prodrug when both nitrogens are protonated (form I);

$\mathrm{f}^{\mathrm{p}}=$ fraction of total prodrug when $\mathrm{N}$ in imidazoline ring is unprotonated but $\mathrm{N}$ in piperazine ring is protonated (form II);

$\mathrm{f}^{\mathrm{up}}=$ fraction of the total prodrug when both nitrogens are unprotonated (form III);

$\mathrm{k}_{\mathrm{H}}=$ second order rate constant for acid catalyzed degradation;
$\mathrm{k}_{\mathrm{OH}}=$ second order rate constant for base catalyzed degradation.

$\mathrm{f}^{\mathrm{pp}}, \mathrm{f}^{\mathrm{p}}$ and $\mathrm{f}^{\mathrm{up}}$ were calculated from the ionisation constant $\mathrm{pKa} 2.5$ for the nitroimidazole and $\mathrm{pKa} 8.8$ for the piperazine nitrogen. 


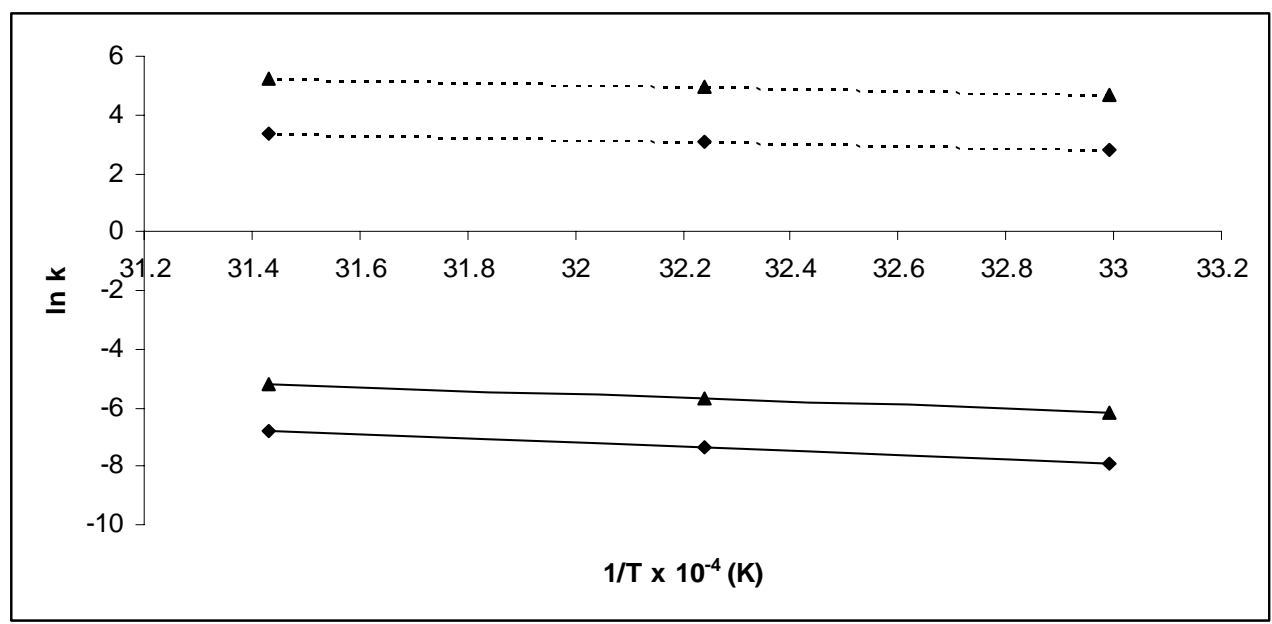

Figure 4: Arrhenius plot for degradation of metronidazole and prodrug at $\mathrm{pH} 2(\bullet)$ and $\mathrm{pH} 9$

$(\boldsymbol{\Delta})$. Smooth lines are for drug and broken for prodrug.

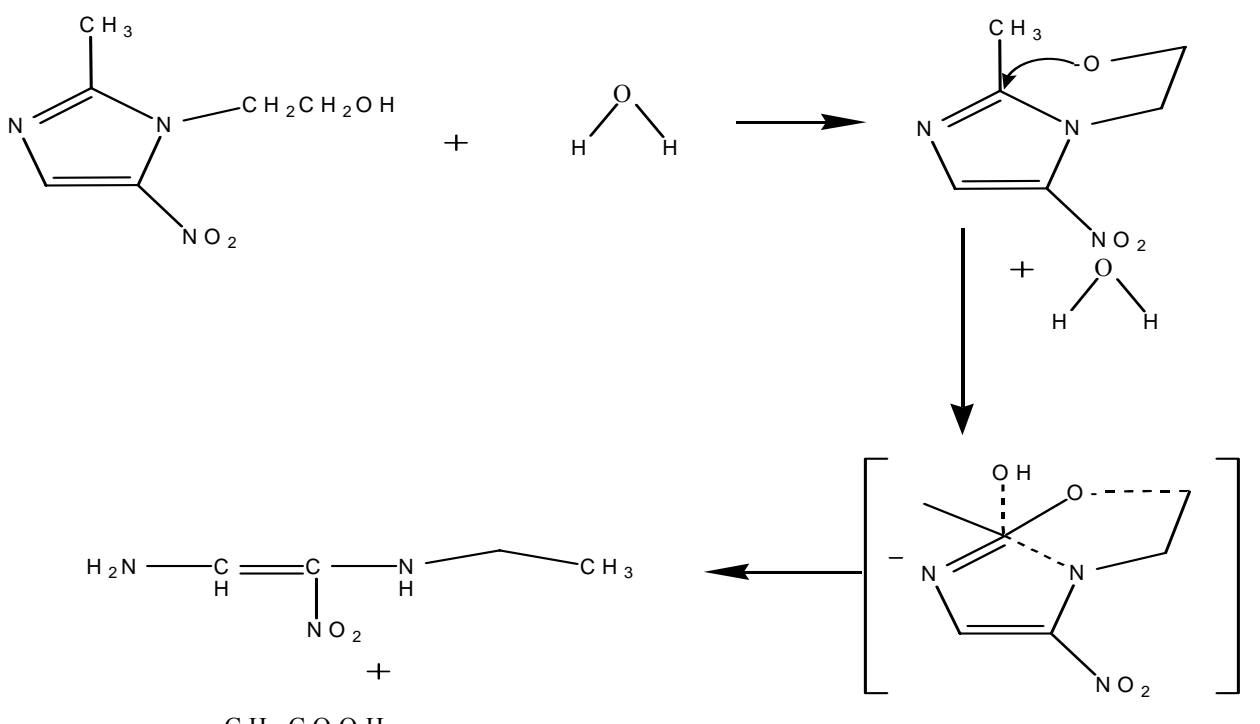

Figure 5: Scheme depicting degradation/hydrolysis of metronidazole.

The observed values are compared with the calculated values in table 3 . The values of various macro-constants are given in table 7 .

The increased rate of reaction at $\mathrm{pH} 2$ may be attributed to the inductive effect of protonated nitrogen of imidazole ring $(\mathrm{pKa}$ 2.5) in form I. However, protonation of nitrogen in piperazine ring in ciprofloxacin reveals no effect due to its long distance from phenyl group and its reduced electron withdrawing effect. Therefore, forms II and III contribute equally towards degradation of prodrug. To our knowledge there is no literature for the rate constants under these experimental conditions but, however, the $\mathrm{pH}$ rate profile follows the same pattern as for other prodrugs of metronidazole (Bowden et al., 1997). The temperature dependence of drug and its prodrug was aimed to determine the optimum $\mathrm{pH}$ for the maximum stability. The linearity $(r=0.997)$ of the plot of $\log$ of $k$ vs $1 / t$ shows a good indication of invariant activation energy for degradation of metronidazole and prodrug in this temperature range. We have also calculated the activation energy for individual rate constants along with other Arrhenius parameters which are given in table 8. This table indicates small enthalpy of 
<smiles></smiles><smiles>[R]OC(=O)c1cn(C2CC2)c2cc(N3CCNCC3)c(F)cc2c1=O</smiles><smiles>[R]OC(=O)C1=CN(C2CC2)c2cc(N3CCNCC3)c(F)cc2C1(C)O</smiles><smiles>[R]O[CH-][C@H]1OC1=O</smiles><smiles>[R]OC1([O-])OC12OC2(O)c1cc(F)c(N2CCNCC2)cc1N1CC1</smiles><smiles>[3H][3H]</smiles><smiles>[R]O[Na]</smiles>

Where<smiles>[R][As][Na]</smiles>

Figure 6: Scheme depicting hydrolytic degradation of prodrug.

activation for the hydrolysis of prodrug as compared to drug. This small $\Delta \mathrm{H}^{\ddagger}$ accompanied by large negative entropy of activation $\Delta \mathrm{S}^{\ddagger}$ is associated with facile intramolecular catalysis by keto group in prodrug (Bowden, 1995).

The present results reveal that utilization of calorimetric technique to study degradation and hydrolytic kinetics is a successful approach. The drug was found to most stable between $\mathrm{pH} 4-6$. The proposed mechanism for degradation of metronidazole at higher $\mathrm{pH}$ is supported by the magnitude of exothermic enthalpy accompanying the degradation.

\section{ACKNOWLEDGEMENT}

The financial assistance provided by University Grants Commission is gratefully acknowledged.

\section{REFERENCES}

Angberg M, Nystrom M, Castensson S. 1988. Evaluation of heat conduction microcalorimetry in pharmaceutical stability studies. Acta. Pharma. Suec., 25: 307-320.

Baveja SK, Khosla HK. 1975. Decomposition of metronidazole in aqueous solutions. Indian J. Technol., 13: 528. 
Baveja SK, Rao AVR. 1973. Kinetics of metronidazole hydrolysis. Indian $J$. Technol., 11: 311-312.

Beezer AE. 2001. An outline of new calculation methods for the determination of both thermodynamic and kinetic parameters from isothermal heat conduction microcalorimetry. Thermochimica Acta, 380: 205-208.

Beezer AE, Gaisford S, Hills AK, Willson RJ, Mitchell JC. 1999. Pharmaceutical microcalorimetry: applications to longterm stability studies. Int. J. Pharm., 179: 159-165.

Bowden K. 1995. Intramolecular catalysis: carbonyl groups in ester hudrolysis. Chem. Soc. Rev., 24:431-435.

Bowden K., Izadi J. 1997. 'Prodrugs - Part 2. Acylbenzoate esters of metronidazole. Eur. J. Med. Chem., 32: 995-1000.

Buckton G, Beezer AE. 1991. The application of microcalorimetry in the field of physical pharmacy. Int. J. Pharm., 72: 181-191.

Chadha R, Kashid N, Jain DVS. 2003a. Kinetic studies of degradation of an aminopenicillin antibiotic (amoxicillin trihydrate) in aqueous solution using heat conduction microcalorime. J. Pharm. Pharmcol., 55: 1495-1503.

Chadha R, Kashid N, Jain DVS. 2003 b. Kinetics of degradation of diclofenac sodium in aqueous solution determined by a calorimetric method. Pharmazie, 58:631-635.

Freeman CD, Klutman NE, Lamp KC. 1997. Metronidazole. A therapeutic review and update. Drugs, 54: 679-708.

Goldstein EJC, Citron DM. 1991. Susceptibility of Anaerobic Bacteria Isolated from Intra-abdominal Infections to Ofloxacin and Interaction of Ofloxacin with Metronidazole. Antimicrob. Agents Chemother., 35: 2447-2449.

Houben MH, Hensen EF, Rauws EA, Hulst RW, Hoff BW, Ende AV, Kate FJ, Tytgat GN. 1999. Randomized trial of omeprazole and clarithromycin combined with either metronidazole or amoxycillin in patients with metronidazole-resistant or -susceptible Helicobacter pylori strains. Aliment. Pharmacol. Ther., 13: 883-889.

Johnansen M, Larsen C. 1984. Stability and kinetics of hydrolysis of metronidazole monosuccinate in aqueous solution and in plasma. Int. J. Pharm., 21: 201-209.

Johnansen M, Larsen C. 1985. A comparison of the chemical stability and enzymatic hydrolysis of a series of aliphatic and aromatic ester derivatives of metronidazole. Int. J. Pharm., 26: 227 241.

Mahtouz NM, Eadl TK, Diab AK. 1998. Metronidazole twin ester prodrugs: synthesis, physico-chemical properties, hydrolysis kinetics and antigiardial activity. Eur. J. Med. Chem., 33: 675 683.

Mimura T, Rizzello F, Helwig U, Poggioli G, Schreiber S, Talbot IC, Nicholls RJ, Gionchetti P, Campieri M, Kamm MA. 2002. Four-week open-label trial of metronidazole and ciprofloxacin for the treatment of recurrent or refractory pouchitis. Ailment. Pharmacol. Ther., 16: 909-917.

O'Keefe JP, Troc KA, Thompson KA. 1982. Activity of metronidazole and its hydroxyl and acid metabolites against clinical isolates of anaerobic bacteria. Antimicrob. Agents Chemother., 22: 426430.

Oliyai R, Lindenbaum S. 1991. Stability testing of pharmaceutical by isothermal heat conduction microcalomitry: ampicillin in aqueous solution. J. Pharm. Sci., 73: 30-36.

Pavicit MJ, Winkelhoff AJ, Graaff J. 1992. In vitro susceptibilities of Actinobacillus actinomycetemcomitans to a number of antimicrobial combinations. Antimicrob. Agents Chemother., 36: 2634-2638.

Phipps MA, Mackin LA. 2000. Application of isothermal microcalorimetry in solid-state drug development. PSTT, 3: 9-17.

Prantera C, Zannoni F, Scribano ML, Berto E, Andreoli A, Kohn A, Luzi C. 1996. An antibiotic regimen for the treatment of active Crohn's disease: a randomized, controlled clinical trial of metronidazole plus ciprofloxacin. Am. J. Gastroenterol., 91: 328-332.

Ralph ED, AmatnieksYE. 1980. Potentially synergistic antimicrobial combinations with metronidazole against Bacteroides fragilis. Antimicrob. Agents Chemother., 17: 379-382. 
Salo JP, Salomies H. 1996. High performance thin layer chromatographic analysis of hydrolyzed tinidazole solutions. II. Hydrolysis kinetics of tinidazole. $J$. Pharm. Biomed. Anal., 14: 1261-1266.

Samuelson J. 1999. Why metronidazole is active against both bacteria and parasites. Antimicrob. Agents Chemother., 43: 1533-1541.

Shen B, Achkar JP, Lashner BA, Ormsby AH, Remzi FH, Brzezinski A, Bevins CL, Bambrick ML, Seidner DL, Fazio VW. 2001. A randomized clinical trial of ciprofloxacin and metronidazole to treat acute pouchitis. Inflamm. Bowel Dis., 7: 301-305.

Skaria CV, Gaisford S, O'neill MA, Buckton G, Beezer AE. 2005. Stability assessment of pharmaceuticals by isothermal calorimetry: two component systems. Int. J. Pharm., 292: 127-135.

TCP (The Controller of Publications). 1996. Indian Pharmacopoeia. Vol. 2. The
Controller of Publications: New Delhi; A146-A147.

Vermeersch H, Remon JP, Permentier D, Schacht E. 1990. In vitro antitrichomonal activity of water-soluble prodrug esters of metronidazole. Int. J. Pharm., 60: 253260.

Wang DP, Yeh MK. 1993. Degradation kinetics of metronidazole in solution. $J$. Pharm. Sci., 82: 95-98.

Werk R, Schneider L. 1988. Ciprofloxacin in combination with metronidazole. Infection., 16: 257-260.

Whiting JH, Cheng N, Chow AW. 1987. Cefoxitin, Cefotaxime, and Mezlocillin against Gram-Positive and GramNegative Anaerobic Bacteria. Antimicrob. Agents Chemother., 31: 1379-1382.

Yang C, Gao H, Mitra AK. 2001. Chemical stability, enzymatic hydrolysis, and nasal uptake of amino acid ester prodrugs of acyclovir. J. Pharm. Sci., 90: 617-624. 